\title{
Biogeochemistry and dissolved oxygen dynamics at a subglacial upwelling, Midtre Lovénbreen, Svalbard
}

\author{
T.D.L. IRVINE-FYNN, A.J. HODSON \\ Department of Geography, University of Sheffield, Winter Street, Sheffield S10 2TN, UK \\ E-mail: t.irvine-fynn@sheffield.ac.uk
}

\begin{abstract}
There is a growing awareness that biological processes affect solute acquisition in glacial meltwaters. An unprecedented, high-resolution record of dissolved oxygen (DO) in emergent subglacial meltwaters at polythermal Midtre Lovénbreen, Svalbard, is discussed in conjunction with the major-ion chemistry of periodic water samples within the catchment. The subglacial outburst increased solutes passing through the proglacial area and was coupled to a seasonal transition in upwelling character from suboxic waters to those with large diurnal fluctuations in the levels of DO saturation, latterly returning to sustained suboxic runoff. During the period of daily variation, DO correlated positively with discharge and inversely to total dissolved solute concentration. Consideration of $\mathrm{SO}_{4}{ }^{2-}$ concentrations showed they exceed those achievable with complete consumption of DO in saturated supraglacial meltwater, and dissolution experiments illustrated protracted abiotic sulphide oxidation remains an unlikely cause. Similarly, relatively elevated ratios of $\mathrm{NO}_{3}{ }^{-} / \mathrm{Cl}^{-}$preclude denitrification aiding the catalysis of sulphide oxidation. Results here tentatively suggest sulphide oxidation is mediated by both aerobic and anoxic biochemical processes and that transition metals are the most likely oxidants. Bacteria are shown to impart a major control on the ionic composition of subglacial upwelling with variability in the ratio of oxygenated surface meltwaters and suboxic subglacial waters.
\end{abstract}

\section{INTRODUCTION}

Hydrochemical studies of subglacial meltwaters emerging from beneath Arctic glaciers have revealed that significant solute enrichment takes place in rock-water contact environments with little access to atmospheric gases (e.g. Vatne and others, 1996; Wadham and others, 1998; Skidmore and Sharp, 1999). Despite this constraint, chemical weathering rates are often comparable to continental averages (Hodson and others, 2000), which several researchers have suggested reflects the efficacy of microbial catalysis of key rockweathering reactions beneath the ice (Wadham and others, 2001; Wynn and others, 2006, 2007). With increasing isolation, subglacial meltwater chemistries are thought to depend more and more upon the provision of acidity $\left(\mathrm{H}^{+}\right)$ from the oxidation of sulphides (Raiswell and Thomas, 1984; Skidmore and others, 2010; Wadham and others, in press). Equations (1-3) below show how this oxidation is achieved using a range of oxidants, beginning with the dissolved atmospheric $\mathrm{O}_{2}$ (DO) in the snow- and/or ice melt entering the glacier (Equation (1)). Observations of glacial runoff suggest that $\mathrm{SO}_{4}{ }^{2-}$ concentrations often exceed the maximum value that may be produced by the DO content of meltwaters entering the glacier via crevasses (e.g. Hodson and others, 2000; Tranter and others, 2002), indicating the use of alternative oxidants, as exemplified by Equations (2) and (3).

$$
\begin{aligned}
& 4 \mathrm{FeS}_{2(\mathrm{~s})}+15 \mathrm{O}_{2(\mathrm{aq})}+14 \mathrm{H}_{2} \mathrm{O}_{(\mathrm{l})} \\
& \leftrightarrow 8 \mathrm{SO}_{4}{ }^{2-}{ }_{(\mathrm{aq})}+4 \mathrm{Fe}(\mathrm{OH})_{3(\mathrm{~s})}+16 \mathrm{H}^{+}{ }_{(\mathrm{aq})} \\
& \mathrm{FeS}_{2(\mathrm{~s})}+14 \mathrm{Fe}^{3+}{ }_{(\mathrm{aq})}+8 \mathrm{H}_{2} \mathrm{O}_{(\mathrm{l})} \\
& \leftrightarrow 2 \mathrm{SO}_{4}{ }^{2-}{ }_{(\mathrm{aq})}+15 \mathrm{Fe}^{2+}{ }_{(\mathrm{aq})}+16 \mathrm{H}^{+}{ }_{(\mathrm{aq})} \\
& 5 \mathrm{FeS}_{2(\mathrm{~s})}+14 \mathrm{NO}_{3}{ }_{(\mathrm{aq})}+4 \mathrm{H}^{+}{ }_{(\mathrm{aq})} \\
& \leftrightarrow 5 \mathrm{Fe}^{2+}{ }_{(\mathrm{aq})}+10 \mathrm{SO}_{4}{ }^{2-}{ }_{(\mathrm{aq})}+7 \mathrm{~N}_{2(\mathrm{~g})}+7 \mathrm{H}_{2} \mathrm{O}_{(\mathrm{l})}
\end{aligned}
$$

To date, knowledge concerning the relative importance of these different oxidants remains elusive. Studies from marine environments have shown that these alternatives are kinetically unfavourable unless microorganisms are directly involved (e.g. Schippers and Jørgensen, 2001). The implication, therefore, is that bacteria are also active under many glaciers with high $\mathrm{SO}_{4}{ }^{2-}$ yields (Sharp and others, 1999; Skidmore and others, 2005) and that $\mathrm{SO}_{4}{ }^{2-}$ production from suboxic environments is an ideal fingerprint for microbial life between ice sheets (e.g. Hodgson and others, 2009).

Within the context presented above, it is clear that the subglacial hydrology and biogeochemistry of Arctic glaciers may be better understood if the DO status of meltwaters emerging from glaciers can be linked to the oxygen demands imposed by abiotic and microbially mediated oxidation reactions occurring in different subglacial environments. Here we address this research need by coupling highresolution time series of total dissolved solids, DO and runoff to sulphide oxidation in a subglacial flowpath beneath Midtre Lovénbreen, Svalbard, during the summer of 2005.

\section{FIELD SITE}

Midtre Lovénbreen is a small $5.2 \mathrm{~km}^{2}$ valley glacier in northwest Svalbard $\left(78^{\circ} 54^{\prime} \mathrm{N}, 11^{\circ} 80^{\prime} \mathrm{E}\right.$; Fig. 1). Negative mass balance of the glacier has dominated since 1968, with accelerating ice losses reaching the contemporary rates of $-0.69 \mathrm{~m}$ w.e. $\mathrm{a}^{-1}$ (Kohler and others, 2007). The geology of the catchment can be broadly summarized as metamorphic phyllites and schists, with bands of quartzite, to the south and sandstones, chert and carbonates to the north (Hjelle, 1993). All these rocks contain pyrite and at least trace amounts of carbonate.

Midtre Lovénbreen is polythermal: temperate ice is sourced in the uppermost cirques (Zwinger and Moore, 2009), extending $\sim 2.5 \mathrm{~km}$ down-glacier as a layer at the 


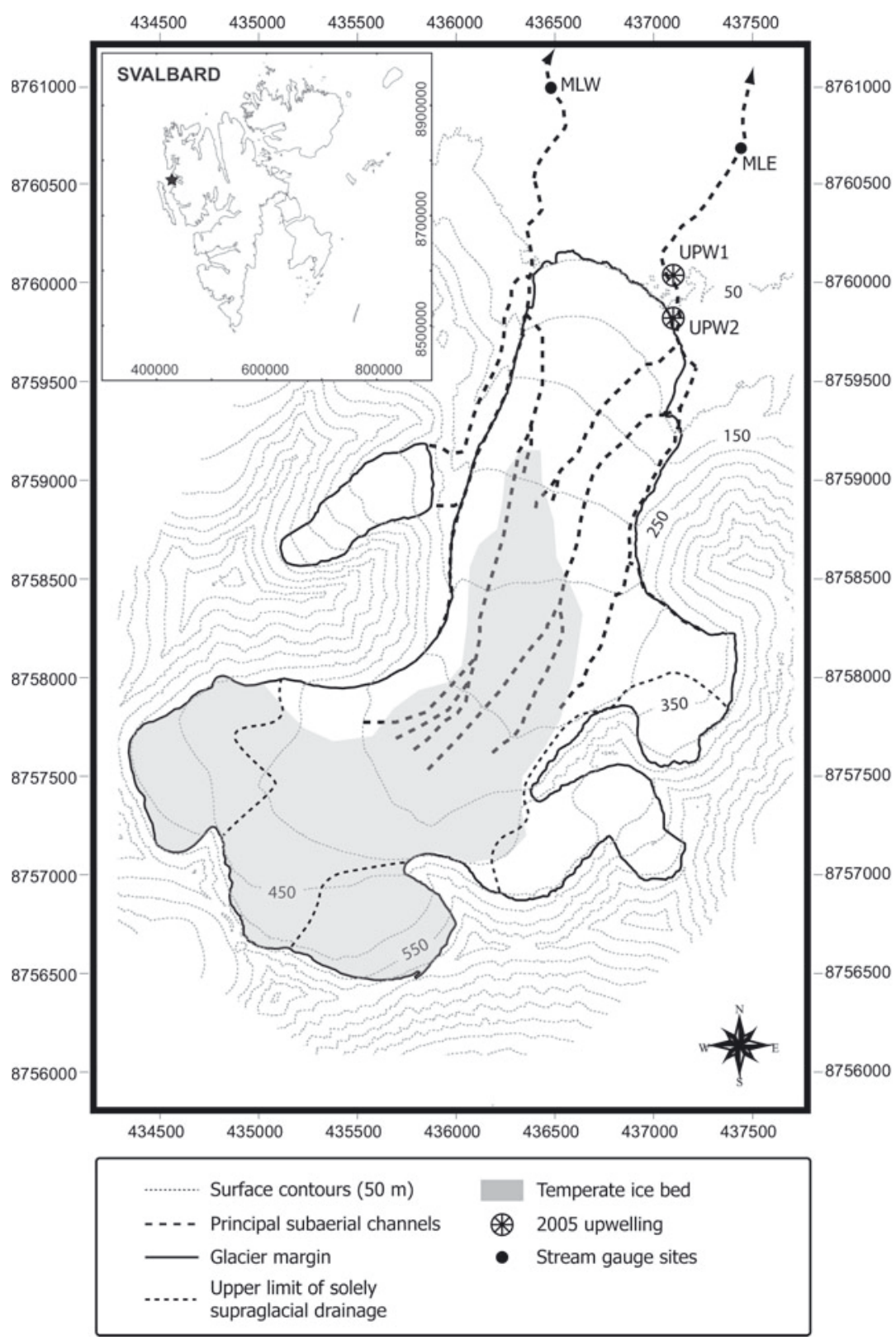

Fig. 1. Location map of Midtre Lovénbreen, for 2005, highlighting river gauging stations (MLE and MLW), upwellings (UPW1 and UPW2), the likely extent of temperate ice at the glacier bed (after Björnsson and others 1996; Rippin, 2002; Zwinger and Moore, 2009) and the approximate lower limits of surface micro-catchments that drain into the glacier.

ice-bed interface with a maximum depth of $\sim 50 \mathrm{~m}$ (Björnsson and others, 1996; Rippin and others, 2003). Annual flow velocities are $<8 \mathrm{~m} \mathrm{a}^{-1}$ (Liestøl, 1988; Björnsson and others, 1996; Rippin and others, 2005). It is where the cirques join the main glacier that surface-derived meltwaters enter the glacier. At lower elevations, meltwaters drain entirely via supraglacial drainage pathways that transfer $\sim 75 \%$ of the annual melt (Fig. 1; Hodson and others, 2005b; Irvine-Fynn, 2008). Dye-tracer passage through the en/ subglacial drainage system revealed moderately rapid mean transit velocities of $\sim 0.3 \mathrm{~m} \mathrm{~s}^{-1}$, suggesting a typical throughflow time of $<5$ hours and not unlike the supraglacial streams (Irvine-Fynn and others, 2005a). However, annual water budgets for 1997-2002 have indicated runoff yields are also strongly influenced by storage within the glacier's drainage system, especially before the meltwaters entering the glacier have begun to emerge as a pressurized upwelling in the glacier forefield (Hodson and others, 2005b).

\section{DATA COLLECTION}

During the ablation season, bulk meltwater from the glacier consistently occupied two key routes: one to the east and one to the west (hereafter MLE and MLW; see Fig. 1). In the summer of 2005, two subglacial upwellings occurred to the east of the glacier centre line (Fig. 1). The first, UPW1, emerged on day of year (DOY) 182 and the second (UPW2) on DOY 213. Druck pressure transducers and Campbell 207 electrical conductivity probes were used to measure hourly averages of hydrological variables in MLE and MLW (see Irvine-Fynn and others, 2005b). Uncertainty in discharge, $Q$, in MLE was $<6 \%$ and $16 \%$ in MLW. Electrical conductivity (manufacturer's accuracy of $\pm 10 \%$ ) was also monitored at the artesian discharge point of UPW1. All conductivity series were transformed into continuous total dissolved ionic solutes $\left(\mathrm{TDS}_{\mathrm{i}}\right)$ by regression analysis with an uncertainty of $\pm 1.9 \%, \pm 3.2 \%$ and $\pm 2.0 \%$ at MLE, MLW and UPW 1 , respectively. Dissolved $\mathrm{O}_{2}$ was measured alongside $\mathrm{TDS}_{\mathrm{i}}$ at 
UPW1 using an OxyGuard CS512 DO sensor (maximum uncertainty $<0.2 \mathrm{mg} \mathrm{L}^{-1}$ ). Sensor drift did not occur, at least according to the periodic DO sensor maintenance undertaken to eliminate biofouling or sediment influence on sensor response.

Sampling of meltwater was undertaken at MLE, MLW, UPW1, and UPW2 at intervals typically $\leq 48$ hours. Opportunistic sampling was also conducted upon the glacier where meltwaters descended into crevasses. All samples were taken manually and handled according to the protocol detailed by Hodson and others (2005a). Samples were filtered within 6 hours of abstraction and then stored, airtight, at $4{ }^{\circ} \mathrm{C}$ prior to major-ion analysis by Dionex 1CS-90 ion chromatography (precision $<10 \%$ for solute described here) within 3 months of the field campaign. Concentrations of $\mathrm{HCO}_{3}{ }^{-}$were estimated using charge balance errors.

\section{RESULTS}

Figure 2 includes the time series of hydrometeorological observations made during 2005. Peak $Q$ was reached on day of year (DOY)188, being 2.63 and $1.46 \mathrm{~m}^{3} \mathrm{~s}^{-1}$ at MLE and MLW, respectively, coincident with seasonal peak air temperatures. Lower $Q$, coupled with elevated $\operatorname{TDS}_{\mathrm{i}}$, was apparent during a cool period (DOY194-199). Following DOY200 until the termination of observations, MLW was characterized by a stable period of diurnally oscillating discharge with a mean of $0.32 \mathrm{~m}^{3} \mathrm{~s}^{-1}$. Subglacial waters emerged on DOY182 at UPW1 beginning as a small turbid effusion, but gradually enlarged to an artesian fountain up to $\sim 0.7 \mathrm{~m}$ which showed decreasing trend over the latter half of the observation period. The effect of UPW1 was to increase the volume of water passing through MLE compared to that gauged at MLW. The emergence of subglacial water also increased $\mathrm{TDS}_{\mathrm{i}}$ in MLE by $\sim 750 \mu \mathrm{EqL}^{-1}$ and weakened the correlation between $Q$ and $\operatorname{TDS}_{\mathrm{i}}(r=-0.4)$ compared to MLW $(r=-0.6)$. Figure 2 shows that $\mathrm{TDS}_{\mathrm{i}}$ at UPW1 displayed far less variability than bulk meltwaters monitored at MLE and MLW. The second upwelling (UPW2) appeared on DOY213 and combined, the upwellings contributed to a mean difference in $Q$ between MLW and MLE of $\sim 0.6 \mathrm{~m}^{3} \mathrm{~s}^{-1}$. Interestingly, MLE, MLW and UPW1 all evidenced TDS peaking at $\geq 2500 \mu \mathrm{Eq} \mathrm{L}^{-1}$ towards the close of the ablation season. Concentrations of $\mathrm{SO}_{4}{ }^{2-}$ at UPW1 tracked $\mathrm{TDS}_{\mathrm{i}}$ closely $(r=0.89)$ and contributed up to $980 \mu \mathrm{Eq} \mathrm{L}^{-1}(34 \%)$ of the ion load at the end of the observation period. There was a remarkable similarity between the $\mathrm{SO}_{4}{ }^{2-}$ content of UPW1 and UPW2 (Fig. 2), which was also the case for the other major ions in subglacial outburst waters (data not shown).

The DO time series is presented in Figure 2 as hourly averages. Dissolved oxygen saturation for waters $<1^{\circ} \mathrm{C}$, as recorded at UPW1, is $14.1 \mathrm{mg} \mathrm{L}^{-1}$ at typical atmospheric pressure (Lewis, 2006). Thus, the upwelling waters were initially suboxic $\left(<10 \mathrm{mg} \mathrm{L}^{-1}\right)$ and gradually approached supersaturation ( $\left.\sim 15 \mathrm{mg} \mathrm{L}^{-1}\right)$ on DOY190. Subsequently, as proglacial discharge fell, UPW1 water returned to a suboxic state until DOY205. Following DOY208, the DO time series was characterized by marked diurnal oscillations until DOY230, which were significantly correlated to $Q(r=0.30$, $p<0.01)$, but inversely correlated to $\operatorname{TDS}_{\mathrm{i}}(r=-0.32$, $p<0.01$ ). A lag time of 3 hours was identified by crosscorrelation, with $Q$ leading DO $(r=0.39)$. The initiation of UPW2 on DOY213 appeared to have had no impact upon either the TDS $\mathrm{i}_{\mathrm{i}}$ or DO records at UPW1.

\section{DISCUSSION}

The evolution from suboxic initial subglacial outburst waters towards saturation is thought to be an annual occurrence at Midtre Lovénbreen according to spot samples (e.g. Wynn and others, 2006). However, high-resolution dynamics had yet to be reported at this or any other glacier, although a twice-daily spot sampling campaign has been described at Haut Glacier d'Arolla, Switzerland (Brown and others, 1994). There, DO variations were inversely related to $Q$, both in bulk and supraglacial meltwaters, leading Brown and others (1994) to speculate that shorter residence times during peak melt and low ice $\mathrm{O}_{2}$ content control DO concentrations. This is in stark contrast to the present study, since there is a positive correlation between $\mathrm{DO}$ and $Q$ and a negative correlation between DO and $\mathrm{TDS}_{\mathrm{i}}$ (see above). The strong inverse relationship between DO and $\mathrm{TDS}_{\mathrm{i}}$ in the interval DOY208-230, therefore, suggests that daily variations in the mixing ratio of oxygenated surface meltwaters and suboxic or perhaps even anoxic subglacial waters take place at Midtre Lovénbreen. Seasonal variations in DO also suggest that the mixing ratio of these flow paths changes, perhaps in response to drainage system evolution throughout the summer. Furthermore, the changes contrast markedly to those proposed by Wynn and others (2006) for this site because suboxic waters are apparent throughout the summer but at a time of the day when Wynn and others (2006) were not conducting their spot sampling.

Confirmation that surface meltwaters were well oxygenated was acquired by in situ analysis of the supraglacial stream DO levels using Winkler titration. A total of 11 analyses between mid-July and mid-August at a range of sites yielded DO levels of $13.2 \pm 1.24 \mathrm{mg} \mathrm{L}^{-1}$ and thus close to saturation. Furthermore, melt experiments using snow, glacier ice and superimposed ice samples in the laboratory indicated supersaturation with DO relative to the atmosphere. The DO levels in five successive melt fractions were $104-120 \%$ saturated, the snow samples being responsible for the greatest levels upon initial melting. In addition to the snowmelt source, oxygen supersaturation may occur through turbulent dissolution as meltwaters cascade down the hydrologically active crevasses. Therefore, surfacederived waters at Midtre Lovénbreen almost certainly enter the glacier close to $\mathrm{O}_{2}$ saturation.

Atmospheric sources of $\mathrm{SO}_{4}{ }^{2-}$ cannot explain the high levels observed in Figure 2. For example, $\mathrm{SO}_{4}{ }^{2-} / \mathrm{Cl}^{-}$ratios in UPW1 and UPW2 (not shown) were 50-250 times those typical of the local snowpack according to Hodson and others (2000). The potential for $\mathrm{SO}_{4}{ }^{2-}$ production following Equation (1) was therefore estimated from the depletion of DO in upwelling waters shown in Figure 2, by assuming that surface waters entering the glacier at $\sim 0^{\circ} \mathrm{C}$ were saturated with respect to the atmosphere. The resulting $\mathrm{SO}_{4}{ }^{2-}$ quantity, hereafter $* \mathrm{SO}_{4}{ }^{\text {oxic }}$, therefore represents the maximum potential for $\mathrm{SO}_{4}{ }^{2-}$ production by Equation (1) if no other $\mathrm{O}_{2}$ sources or sinks are assumed to exist within the glacier. Figure 2 shows $* \mathrm{SO}_{4}{ }^{\text {oxic }}$ alongside the observed $\mathrm{SO}_{4}{ }^{2-}$ at UPW1 and UPW2. Two key observations emerge:

1. Aerobic oxygenation of sulphide is an insufficient source of the observed $\mathrm{SO}_{4}{ }^{2-}$ prior to DOY 208 and after DOY 230. During these periods, $\mathrm{SO}_{4}{ }^{2-}$ levels in UPW1 and UPW2 often exceed concentrations achievable with complete consumption of DO in saturated supraglacial meltwater by Equation (1). 


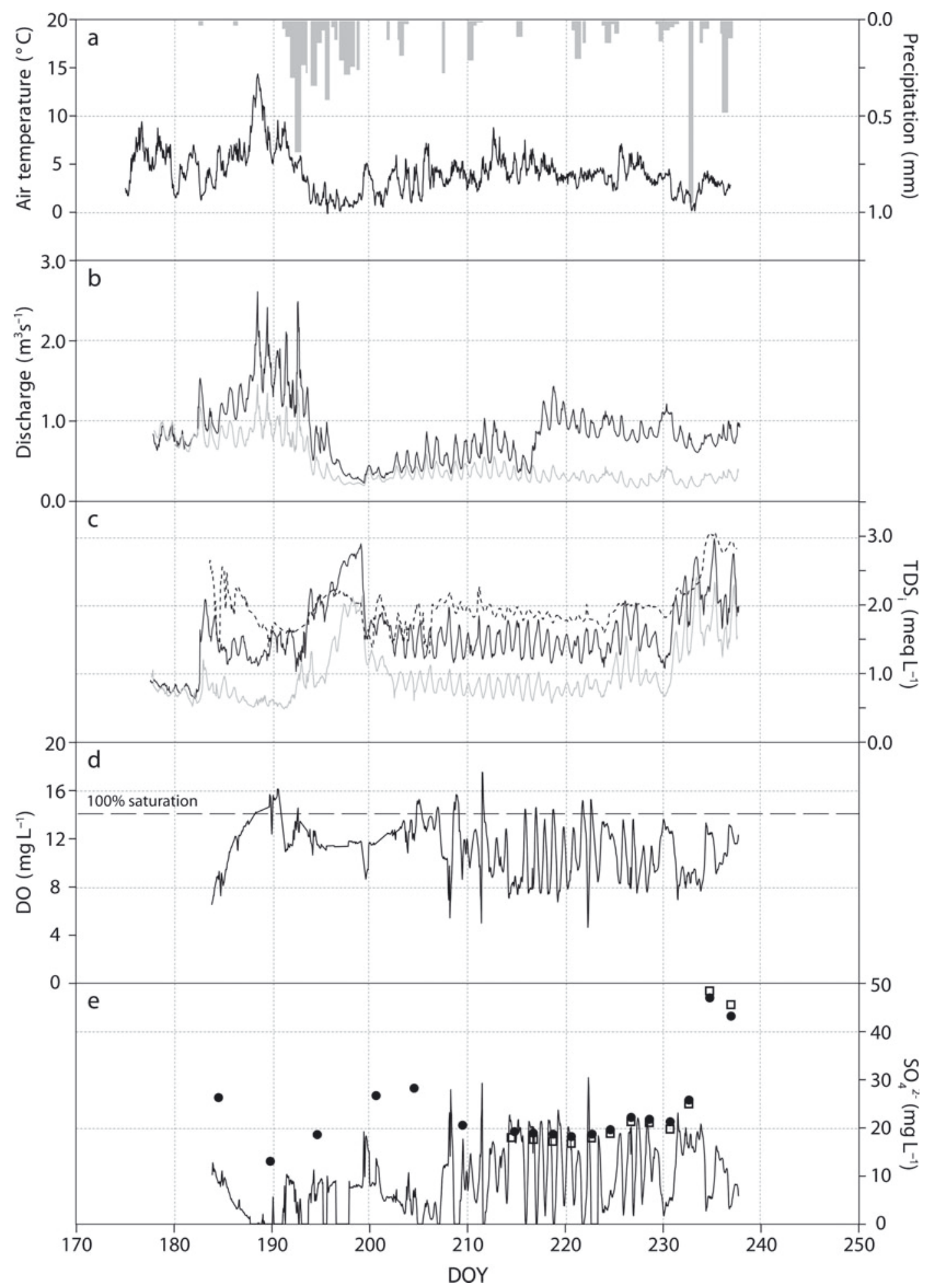

Fig. 2. Time series of: (a) air temperature recorded at $150 \mathrm{~m}$ a.s.I. on the glacier snout and precipitation events; (b) $Q$ for MLE (black) and MLW (grey); (c) TDS ${ }_{i}$ at MLE (black), MLW (grey) and UPW1 (dotted); (d) DO recorded at UPW1; and (e) * $\mathrm{SO}_{4}{ }^{\text {oxic }}$ at UPW1 (line) and observed $\mathrm{SO}_{4}{ }^{2-}$ at UPW1 (dot) and UPW2 (square).

2. Estimates of $* \mathrm{SO}_{4}{ }^{\text {oxic }}$ are close to the observed $\mathrm{SO}_{4}{ }^{2-}$ concentrations during the main phase of the ablation season, when strong diurnal variations in DO were sampled, usually at the time of high DO in the afternoon.

Given the above, it is tempting to propose that aerobic oxidation of sulphide minerals is a sufficient explanation for the mid-season levels of $\mathrm{SO}_{4}{ }^{2-}$ observed in subglacial outflow, at least during peak flows. An analysis of the kinetics of $\mathrm{SO}_{4}{ }^{2-}$ acquisition over timescales relevant to meltwater passage through the glacier was therefore undertaken. Table 1 shows the chemistries of solutions produced in three successive, 24 hour, closed system dissolution experiments at high rock-water contact ratios $\left(1 \mathrm{gL}^{-1}\right)$ of $<125 \mu \mathrm{m}$ freshly crushed bedrock and deionized water. These samples were analysed in the manner described above. All experiments clearly show the effects of carbonate weathering, producing solutions with high $\mathrm{Ca}^{2+}$, low $\mathrm{p}\left(\mathrm{CO}_{2}\right)$ 
Table 1. Major-ion, $\mathrm{pH}, \mathrm{CO}_{2}$ partial pressure $\left(\mathrm{p}\left(\mathrm{CO}_{2}\right)\right)$, sulphate mass fraction (SMF) and saturation index (SI) calculations (produced using Phreeqc software) for $\mathrm{CaCO}_{3}$ following the dissolution experiments. Experimental conditions are described in the text and more closely by Hodson and others (2010). Three successive 24 hour experiments are reported for each major rock type: siliceous sandstone (SSt), phyllite (Phyll), schist/phyllite (Sch/Phyll) and quartzite (Qtz)

\begin{tabular}{|c|c|c|c|c|c|c|c|c|c|}
\hline Rock type & Exp. & $\mathrm{pH}$ & $\mathrm{Ca}$ & $\mathrm{Mg}$ & $\mathrm{HCO}_{3}$ & $\mathrm{pCO}_{2}$ & $\mathrm{SI} \mathrm{CaCO}_{3}$ & $\mathrm{SO}_{4}$ & $\begin{array}{c}\text { SMF } \\
\%\end{array}$ \\
\hline SSt & $\begin{array}{l}1 \mathrm{st} \\
2 \mathrm{nd} \\
3 \mathrm{rd}\end{array}$ & $\begin{array}{l}9.20 \\
9.58 \\
9.63\end{array}$ & $\begin{array}{l}0.19 \\
0.14 \\
0.15\end{array}$ & $\begin{array}{l}0.095 \\
0.088 \\
0.079\end{array}$ & $\begin{array}{l}0.62 \\
0.47 \\
0.47\end{array}$ & $\begin{array}{l}-4.67 \\
-5.22 \\
-5.28\end{array}$ & $\begin{array}{l}0.21 \\
0.29 \\
0.36\end{array}$ & $\begin{array}{l}0.00145 \\
0.00042 \\
0.00032\end{array}$ & $\begin{array}{l}0.46 \\
0.18 \\
0.14\end{array}$ \\
\hline Phyll & $\begin{array}{l}1 \mathrm{st} \\
2 \mathrm{nd} \\
3 \mathrm{rd}\end{array}$ & $\begin{array}{l}8.83 \\
9.62 \\
9.60\end{array}$ & $\begin{array}{l}0.17 \\
0.16 \\
0.16\end{array}$ & $\begin{array}{l}0.009 \\
0.008 \\
0.007\end{array}$ & $\begin{array}{l}0.46 \\
0.40 \\
0.38\end{array}$ & $\begin{array}{l}-4.41 \\
-5.33 \\
-5.33\end{array}$ & $\begin{array}{r}-0.29 \\
0.32 \\
0.29\end{array}$ & $\begin{array}{l}0.00057 \\
0.00010 \\
0.00012\end{array}$ & $\begin{array}{l}0.25 \\
0.05 \\
0.06\end{array}$ \\
\hline Sch/Phyll & $\begin{array}{l}1 \mathrm{st} \\
2 \mathrm{nd} \\
3 \mathrm{rd}\end{array}$ & $\begin{array}{l}8.84 \\
9.46 \\
8.94\end{array}$ & $\begin{array}{l}0.14 \\
0.13 \\
0.07\end{array}$ & $\begin{array}{l}0.006 \\
0.004 \\
0.003\end{array}$ & $\begin{array}{l}0.42 \\
0.32 \\
0.17\end{array}$ & $\begin{array}{l}-4.46 \\
-5.24 \\
-4.9\end{array}$ & $\begin{array}{r}-0.39 \\
0.02 \\
-0.97\end{array}$ & $\begin{array}{l}0.00045 \\
0.00004 \\
0.00005\end{array}$ & $\begin{array}{l}0.21 \\
0.02 \\
0.06\end{array}$ \\
\hline Qtz & $\begin{array}{l}1 \mathrm{st} \\
2 \mathrm{nd} \\
3 \mathrm{rd}\end{array}$ & $\begin{array}{l}8.19 \\
8.43 \\
8.30\end{array}$ & $\begin{array}{l}0.01 \\
0.03 \\
0.03\end{array}$ & $\begin{array}{l}0.005 \\
0.008 \\
0.006\end{array}$ & $\begin{array}{l}0.08 \\
0.10 \\
0.08\end{array}$ & $\begin{array}{l}-4.52 \\
-4.68 \\
-4.62\end{array}$ & $\begin{array}{l}-2.75 \\
-2.03 \\
-2.23\end{array}$ & $\begin{array}{l}0.00472 \\
0.00022 \\
0.00011\end{array}$ & $\begin{array}{r}10.70 \\
0.45 \\
0.28\end{array}$ \\
\hline
\end{tabular}

and saturation with respect to $\mathrm{CaCO}_{3}$ (Table 1). This is typical of early rock-water contact beneath glaciers (e.g. Tranter and others, 2002). However, there is a notable lack of $\mathrm{SO}_{4}{ }^{2-}$ in the solutions, such that $<1 \%$ of the carbonate weathering can be attributed to the neutralization of acidity generated by sulphide oxidation (using Equation (1)). By contrast, the corresponding proportions in the UPW1 and UPW2 samples were approximately $48 \pm 7.3 \%$ and $52 \pm 8.9 \%$, respectively (Irvine-Fynn, 2008).

Following the above argument, aerobic oxidation of sulphide mineral surfaces from suspended sediments as surface waters transit through the en/subglacial drainage system ( $\sim 5$ hours according to dye injections) cannot explain the $\mathrm{SO}_{4}{ }^{2-}$ observed at UPW1 and UPW2. This necessitates an explanation based upon mixing between surface-derived meltwaters and long-residence-time waters draining reactive subglacial sediments throughout the summer. The kinetics of sulphide oxidation during our dissolution experiments suggest that abiotic oxidation remains unlikely. Furthermore, stable-isotopic work at this site has already identified that microbially mediated sulphide oxidation occurs in anoxic environments within the local glacial sediments (Wynn and others, 2006). However, since other bacterial processes are also known to occur where these sediments are not anoxic (e.g. nitrification (Hodson and others, 2005a; Wynn and others, 2007)), it seems reasonable to expect aerobic sulphide oxidation is also being mediated by bacteria.

During the present study, far greater $\mathrm{NO}_{3}{ }^{-} / \mathrm{Cl}^{-}$molar ratios were observed in UPW1 and UPW2 waters (averaging $0.054 \pm 0.011$ for all samples) relative to supraglacial samples of waters descending crevasses (average $\mathrm{NO}_{3}{ }^{-} / \mathrm{Cl}^{-}$ $=0.009 \pm 0.018$ ). Microbial $\mathrm{NO}_{3}{ }^{-}$production therefore appears to have been significant. Furthermore, a positive correlation $(r=0.85)$ between the $\mathrm{NO}_{3}{ }^{-} / \mathrm{Cl}^{-}$ratios of the UPW1 and UPW2 waters and their $\mathrm{SO}_{4}{ }^{2-}$ concentrations seems to rule out denitrification (Equation (3)) as a basis for providing the additional $\mathrm{SO}_{4}{ }^{2-}$ not explained by Equation (1). Consequently, we tentatively propose that transition metals such as Fe(III) (Equation (2)) and $\mathrm{Mn}(\mathrm{IV})$
(Equation (4); Schippers and Jørgensen, 2001) are the most likely oxidants responsible for sulphide oxidation in the anoxic environments:

$$
\begin{aligned}
& 2 \mathrm{FeS}_{2(\mathrm{~s})}+14 \mathrm{MnO}_{2(\mathrm{~s})}+22 \mathrm{H}^{+}{ }_{(\mathrm{aq})} \\
& \rightarrow 2 \mathrm{Fe}(\mathrm{OH})_{3(\mathrm{~s})}+4 \mathrm{SO}_{4}{ }^{2-}{ }_{(\mathrm{aq})}+14 \mathrm{Mn}^{2+}{ }_{(\mathrm{aq})}+8 \mathrm{H}_{2} \mathrm{O}_{(\mathrm{l})} .
\end{aligned}
$$

However, since the isotopic analysis of Wynn and others (2006) does not indicate the anoxic production of $\mathrm{SO}_{4}{ }^{2-}$ during the principal runoff phase (e.g. DOY 208-230), further research into the timing and relative importance of aerobic versus anoxic $\mathrm{SO}_{4}{ }^{2-}$ production appears well justified.

\section{CONCLUSION}

For the first time, a high-resolution DO record has been acquired from subglacial water emerging from Midtre Lovénbreen, an Arctic glacier. This record shows a clear distinction between the polythermal glacier and a temperate glacier, because surface meltwaters are highly oxygenated until they reach the glacier bed, where a clear oxygen demand is present owing to sulphide oxidation. While the same oxygen demand is known beneath temperate glaciers, the impact on DO is apparently masked by low DO levels in ice melt upon the surface and perhaps their re-aeration in turbulent transit through the glacier. The Arctic glacier differs from the temperate glacier on account of a subglacial, rather than supraglacial, control upon DO dynamics in runoff from beneath the glacier. The present study shows the subglacial acquisition of $\mathrm{SO}_{4}{ }^{2-}$ by sulphide oxidation has the capacity to account for more than all of the oxygen depletion observed during the summer. It is, therefore, necessary to invoke microbial catalysis of sulphide oxidation, perhaps in both aerobic and anoxic environments, because the kinetics of abiotic $\mathrm{SO}_{4}{ }^{2-}$ production in dissolution experiments are very slow. Where oxidants other than atmospheric $\mathrm{O}_{2}$ are active, the use of transition metals appears more likely than $\mathrm{NO}_{3}{ }^{-}$because high $\mathrm{SO}_{4}{ }^{2-}$ concentrations in subglacial waters are concomitant with high $\mathrm{NO}_{3}{ }^{-}$following nitrification. 


\section{ACKNOWLEDGEMENTS}

T.I.-F. acknowledges UK Natural Environment Research Council (NERC) standard grant NE/G006253/1 and financing of fieldwork from the Gino Watkins Memorial Fund, the Dudley Stamp Memorial Trust and the University of Sheffield (Department of Geography). A.J.H. acknowledges the University of Sheffield (Knowledge Transfer Fund), the Geological Society's W.G. Fearnsides Fund and the Earth and Space Foundation. N. Cox and S. Marshall (NERC Arctic Research Station), P. Porter and F. Hunter helped with the fieldwork. Dairy Pipe Lines Ltd (Saffron Walden, Essex) are thanked for donation of beverage-grade stainless steel mesh used to house the DO probe. M. Tranter provided useful review comments.

\section{REFERENCES}

Björnsson, H. and 6 others. 1996. The thermal regime of sub-polar glaciers mapped by multi-frequency radio-echo sounding. J. Glaciol., 42(140), 23-32.

Brown, G.H., M. Tranter, M.J. Sharp, T.D. Davies and S. Tsiouris. 1994. Dissolved oxygen variations in Alpine glacial meltwaters. Earth Surf. Process. Landf., 19(3), 247-253.

Hjelle, A. 1993. Geology of Svalbard. Oslo, Norsk Polarinstitutt. (Polarhåndbok 7.)

Hodgson, D.A. and 11 others. 2009. Exploring former subglacial Hodgson Lake, Antarctica Paper I: site description, geomorphology and limnology. Quat. Sci. Rev., 28(23-24), 2295-2309.

Hodson, A.J., M. Tranter and G. Vatne. 2000. Contemporary rates of chemical denudation and atmospheric $\mathrm{CO}_{2}$ sequestration in glacier basins: an Arctic perspective. Earth Surf. Process. Landf., 25(13), 1447-1471.

Hodson, A.J., P.N. Mumford, J. Kohler and P.M. Wynn. 2005a. The High Arctic glacial ecosystem: new insights from nutrient budgets. Biogeochemistry, 72(2), 233-256.

Hodson, A., J. Kohler and M. Brinkhaus. 2005b. Multi-year water and surface energy budget of a high-latitude polythermal glacier: evidence for overwinter storage in a dynamic subglacial reservoir. Ann. Glaciol., 42, 42-46.

Hodson, A. and 6 others. 2010. The structure, biological activity and biogeochemistry of cryoconite aggregates upon an Arctic valley glacier: Longyearbreen, Svalbard. J. Glaciol., 56(196), 349-362.

Irvine-Fynn, T.D.L. 2008. Modelling runoff from the maritime Arctic cryosphere: water storage and routing at Midtre Lovénbreen. (PhD thesis, University of Sheffield.)

Irvine-Fynn, T.D.L., A.J. Hodson, J. Kohler, P.R. Porter and G. Vatne. 2005a. Dye tracing experiments at Midre Lovénbreen, Svalbard: preliminary results and interpretations. In Mavlyudov, B., ed. Glacier Caves and Glacial Karst in High Mountains and Polar Regions: Proceedings of the 7th GLACKIPR Symposium, Sept. 2005, Azau. Moscow, Russian Academy of Sciences. Institute of Geography, 36-43.

Irvine-Fynn, T.D.L. and 7 others. 2005b. Geocryological processes linked to High Arctic proglacial stream suspended sediment dynamics: examples from Bylot Island, Nunavut, and Spitsbergen, Svalbard. Hydrol. Process., 19(1), 115-135.

Kohler, J. and 7 others. 2007. Acceleration in thinning rate on western Svalbard glaciers. Geophys. Res. Lett., 34(18), L18502. (10.1029/2007GL030681.)

Lewis, M.E. 2006. Dissolved oxygen. In Wilde, F.D., ed. National field manual for the collection of water quality data: techniques of water resources investigations. Book 9. Reston, VA, US Geological Survey, A6.

Liestøl, O. 1988. The glaciers in the Kongsfjorden area, Spitsbergen. Nor. Geogr. Tidsskr., 42(4), 231-238.

Raiswell, R. and A.G. Thomas. 1984. Solute acquisition in glacial melt waters. I. Fjallsjökull (south-east Iceland): bulk melt waters with closed-system characteristics. J. Glaciol., 30(104), 35-43.

Rippin, D.M. 2002. The hydrology and dynamics of polythermal glaciers: Midre Lovénbreen, Svalbard. (PhD thesis, University of Cambridge.)

Rippin, D. and 6 others. 2003. Changes in geometry and subglacial drainage of Midre Lovénbreen, Svalbard, determined from digital elevation models. Earth Surf. Process. Landf., 28(3), 273-298.

Rippin, D., I. Willis and N. Arnold. 2005. Seasonal patterns of velocity and strain across the tongue of the polythermal glacier midre Lovénbreen, Svalbard. Ann. Glaciol., 42, 445-453.

Schippers, A. and B.B. Jørgensen. 2001. Oxidation of pyrite and iron sulfide by manganese dioxide in marine sediment. Geochim. Cosmochim. Acta, 65, 915-922.

Sharp, M., J. Parkes, B. Cragg, I.J. Fairchild, H. Lamb and M. Tranter. 1999. Widespread bacterial populations at glacier beds and their relationship to rock weathering and carbon cycling. Geology, 27(2), 107-110.

Skidmore, M.L. and M.J. Sharp. 1999. Drainage system behaviour of a High-Arctic polythermal glacier. Ann. Glaciol., 28, 209-215.

Skidmore, M., S.P. Anderson, M. Sharp, J. Foght and B.D. Lanoil. 2005. Comparison of microbial community compositions of two subglacial environments reveals a possible role for microbes in chemical weathering processes. Appl. Environ. Microbiol., 71(11), 6986-6997.

Skidmore, M., M. Tranter, S. Tulaczyk and B. Lanoil. 2010. Hydrochemistry of ice stream beds- evaporitic or microbial effects? Hydrol. Process., 24(4), 517-523.

Tranter, M., M.J. Sharp, H.R. Lamb, G.H. Brown, B.P. Hubbard and I.C. Willis. 2002. Geochemical weathering at the bed of Haut Glacier d'Arolla, Switzerland - a new model. Hydrol. Process., 16(5), 959-993.

Vatne, G., B. Etzelmüller, R.S. Ødegård and J.L. Sollid. 1996. Meltwater routing in a high Arctic glacier, Hannabreen, northern Spitsbergen. Nor. Geogr. Tidsskr., 50(1), 67-74.

Wadham, J.L., A.J. Hodson, M. Tranter and J.A. Dowdeswell. 1998. The hydrochemistry of meltwaters draining a polythermal-based high Arctic glacier, southern Svalbard. I. The ablation season. Hydrol. Process., 12(12), 1825-1849.

Wadham, J.L., R. Hodgkins, R.J. Cooper and M. Tranter. 2001. Evidence for seasonal subglacial outburst events at a polythermal glacier, Finsterwalderbreen, Svalbard. Hydrol. Process., 15(12), 2259-2280.

Wadham, J.L. and 8 others. 2010. Biogeochemical weathering under ice: size matters. Global Biogeochem. Cycles, 24(3), GB3025. (10.1029/2009GB003688.)

Wynn, P., A. Hodson and T. Heaton. 2006. Chemical and isotopic switching within the subglacial environment of a High Arctic glacier. Biogeochemistry, 78(2), 173-193.

Wynn, P.M., A.J. Hodson, T.H.E. Heaton and S.R. Chenery. 2007. Nitrate production beneath a High Arctic glacier, Svalbard. Chemical Geol., 224(1-2), 88-102.

Zwinger, T. and J.C. Moore. 2009. Diagnostic and prognostic simulations with a full Stokes model accounting for superimposed ice of Midtre Lovénbreen, Svalbard. Cryosphere, 3(2), 217-229. 